\title{
Brexit: Historical and Socio-Political Developments
}

\begin{abstract}
Alessandro Figus
Alessandro Rossetti

Link Campus University,

Rome, Italy

Doi: 10.36941/ajis-2019-0044

\section{Abstract}

BREXIT is a long and difficult process, authors with this contribution try to analyze it. The Brexit referendum is a long way off, but does the debate focus on the practical decisions to be made, how and when will the United Kingdom really come out of the EU? Will England and especially its capital be able to retain the label of a global business goal? How will British politicians limit the profound and long-term consequences of an inevitable recession? The question is not just economic.
\end{abstract}

Keywords: Brexit, European Union, socio-political, referendum, economic

\section{Introduction}

On 23 June 2016, the United Kingdom voted in favor of leaving the European Union, with $51.9 \%$ of voters in favor of "leave".

The result of the Brexit referendum has produced heavy shock waves all over the world, causing financial markets to collapse and reigniting global debates on nationalism, populism and Europe's skepticism in the meantime the fragility of Europe has been highlighted.

In addition, the vote highlights increasingly deeper divisions that cut the traditional lines of British parties. The Brexit also emphasizes the consolidated British Eurosceptic tradition, as well as the deep rifts that exist between the U.K. political elite and Europe.

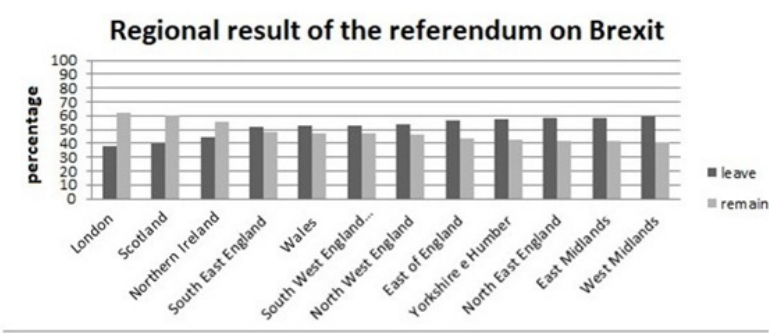

National result of the referendum on Brexit

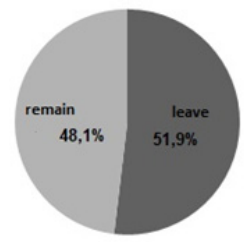


Table ${ }^{1}$ elaborated by the authors.

As shown in the graph, there are three areas where the vote for the "remain" got the majority: London, Scotland and Northern Ireland. It is important to point out that in the eastern part of the British capital; "leave" has prevailed instead.

\section{Brexit - Socio-Historical Approach}

The United Kingdom has always distinguished itself in the European space. For centuries, the Anglo-Saxon cult regarding the independence of political thought had no equal in Europe, not by chance the Magna Carta Libertatum of 1215, a legal instrument that at that time had no analogues in the world, appeared right on the British Islands. Individualism, pragmatism and the ability to innovate have always been the foundation of British political construction.

One of the differences between the Anglo-Saxon mentality and the continental one, is its greater mobility, its readiness to accept changes and to abandon the status quo. The idea of a united Europe impressed the English for a long time, but, as with many ideas, it ended up becoming obsolete. Consequently, instead of continuing to stagnate, complain about the economic and social difficulties, deplore the funds invested in common European activities, England has announced its withdrawal from the EU. This decision is not proof of decline or crisis, but of a transformation taking place within the Union.

The social changes that led to Brexit, began decades ago. The structure of British electorate has began a slow and inexorable changes some decades ago, the structural changes was due to by one hand the increase percentage of graduates and by other hand the decline of labour class and increase of middle class . According to Paul Botton in the 1960s, "more than half of those who had jobs in the UK carried out manual work and less than $10 \%$ of the electorate had a degree" 2 . Analyzing the data of 2000 , we can see that the graduates voters was a third from all electorate and labour class had shrunk to a fifth. In consideration of this data, the electoral calculation for the two main parties, Labour and Conservative, was mainly altered. As states M J. Goodwin: "In earlier years, when the working classes had been dominant, Labour could win power by mobilizing its core working-class support, while the Conservatives had to cultivate cross-class appeal. By the 1990s, however, the shift in the country's class structure had reversed this calculus."

Labor has accused or repeated electoral defeats. During the Tony Blair period, the historical ideology and values of the labor class have been minimized; the middle class was emphasized in the "New Job" that was designed to build the managerial and centrist image.

"Between 1997 and 2010, New Labour sought to attract the middle class and universityeducated professionals, whose numbers were growing rapidly and whose social values on issues such as race, gender, and sexuality were a natural fit with liberalism. This proved highly successful in the short run, keeping Labour in power for 13 years." 4

The price for this success was a less participation at elections and growing of called "disaffection" with the political system due to lost confidence and identification in and with the Labor party

Also during the David Cameron era the white working class was not considered in a country where almost $90 \%$ of the population is still white 5 and the questions about immigration policy

\footnotetext{
${ }^{1}$ Data Source: The Electoral Commission's report on the UK's membership of the EU - The 2016 EU referendum. Graphics (see https://www.electoralcommission.org.uk/).

${ }^{2}$ Data Source: House of Commons Library, Education: Historical statistics. Last updated: 27 November 2012. Author: Paul Bolton.

${ }^{3}$ Data source Matthew J. Goodwin in Brexit: Causes \& Consequences, https://www.jef.or.jp/journal/pdf /216th_Recent_JEF_Activity_02.pdf

${ }_{4}$ Data source Matthew J. Goodwin in Brexit: Causes \& consequences, https://www.jef.or.jp/journal/pdf /216th_Recent_JEF_Activity_02.pdf

${ }^{5}$ Data source : Office of National Statistics, 2011 Census.
} 
would have allowed an orientation of this class to the conservative party. The strategy of David Cameron was "focused instead on trying to "modernize" his party, regaining support from the graduates and middle-class professionals who had drifted away from the Conservatives during the era of Blair."6

The result was the disillusion of voters and finally the apathy of white working class so the apathy of $90 \%$ of electoral population. Eventually, in 2016, many of these voters would therefore continue to vote for Brexit. Unlike those who later voted to remain in the EU, the white working class supported not only harsh responses to criminals and terrorists but also much stricter immigration restrictions. Therefore, the same things that liberals celebrate, namely ethnic diversity, the transition to transnational identities and rapid change, are instead perceived in a threatening way by the majority of the British electorate.

\section{Brexit - Economic Approach}

Having made these remarks, it is necessary to analyze the phenomenon on a supranational scale. The European Union is an association of countries, a unique international entity that combines the characteristics of an international organization with those of a state. All member countries of the European Union, although they are independent, they follow the same EU rules as regards: education, health care, the pension system, the judicial system and legislation in general.

The EU economy appears to be the sum of all the member countries' economies, which contribute with their share of GDP to generate the total; the states that have so far registered the highest revenues are France, Germany, Italy, Spain and the United Kingdom. With the help of a standardized system of laws in force in all EU countries, therefore a common market was created to ensure the free movement of people, goods, capital and services, abolishing passport control within the Schengen area.

For many reasons, the United Kingdom has always played a special role in the European Union. This is probably due to the mentality of the English, mainly shaped on the basis of the geographical position. Great Britain is in fact a huge island, which on the one hand belongs to Europe and on the other does not; this is due to the special "insular psychology" of its inhabitants: for the United Kingdom, the idea of abandon part of its sovereignty by transferring it to a supranational body, was a painful decision.

Historically, the peak of British power came in the nineteenth century. However, at the beginning of the Great War, Britain had lost this economic superiority, which re-emerged only in part, with the victory in the Second World War. Thus, while the Anglo-Saxons, the Americans and the Soviets came out winners from the war, the Germans together with other European states, set about sacrificing part of their sovereignty in favor of a peaceful coexistence on the continent. The British on the contrary proud of the victory tried to strengthen their political weight, preserving this position of exclusivity.

The main objective of the country's foreign policy was the establishment of "special relations" with the United States and the preservation of the British Commonwealth. This required, first of all, to preserve complete freedom of action, which should not have been limited by any political obligation imposed by a future integrated Europe. During the negotiations for the creation of the European Free Trade Area (EFTA), the United Kingdom then tried to maintain the integrity of its agricultural sector, through subsidies that allowed British consumers to buy food at competitive prices. However, this plan was not accepted by the other participants in the negotiations, since it provided a more favorable position for Great Britain.

Following this logic, in 1957 the United Kingdom did not sign the treaties of Rome, the main document of the European Economic Community (EEC), concerning the free movement of people, goods, services and capital. In January 1960, the United Kingdom created its own group, EFTA, without the participation of the main European countries: besides Great Britain,

${ }^{6}$ Data Source Matthew J. Goodwin in Brexit: Causes \& Consequences, https://www.jef.or.jp/journal/pdf /216th_Recent_JEF_Activity_02.pdf 
Austria, Switzerland, Portugal and all the Scandinavian countries were part of it. Subsequently, the United Kingdom realized that the country's economic potential could not coincide with global power status; the decolonization process intensified abruptly, becoming evident that a further orientation of foreign trade towards the Commonwealth countries would no longer be sufficient. Indeed, British industry began to feel the dependence on continental Europe, so much so that on 31 July 1961, Prime Minister G. Macmillan announced that the United Kingdom was intending to apply for membership of the EEC. Only on 1 January 1973, after the formation of new governments in France and Germany, Britain, along with Ireland and Denmark, became part of the Community.

Despite everything, in 1973 in Great Britain there was a discussion about a possible exit; in this regard, a referendum similar to that of June 23 was held in 1975, although a different outcome was achieved (67.2\% of voters in favor of remaining). ${ }^{7}$

British leaders have consistently emphasized that the country has more important foreign policy objectives than participation in European integration; therefore, since the beginning of its stay in the EU, the United Kingdom has acted as "reluctant partner". For a quarter of a century, it has not launched a single major initiative to develop community integration. This position naturally caused strong differences with other European countries in the preparation of the Maastricht Treaty. The British government has insisted on the adoption of a protocol that would have allowed the United Kingdom not to participate in the third phase of integration, namely the creation of an economic and monetary union (EMU). The ratification of the Maastricht treaty caused a harsh political struggle in the English parliament: in fact, about 600 amendments were proposed to the bill indicated by the government ${ }^{8}$.

The change of direction towards the EU took place while Tony Blair was prime minister: his task was indeed to demonstrate that the United Kingdom was a key member in strengthening European integration. The main efforts focused on the development of a new EU economic strategy, the establishment of the European Central Bank with the election of its president, the launch of Europol and negotiations with the candidate countries.

At present, there are several contradictions between the EU and the United Kingdom. The anti-integration sentiments of the British are associated both with the country's historical past, with the old conservatives in favor of a "return to the origins ", and with the relations with the European Union regarding issues ranging from supranational control over the economy to finance, to laws aimed at limiting the expansion of the single market by allowing member countries to block the effect of the Brussels directives.

In the United Kingdom, supporters of transatlantic cooperation have traditionally enjoyed a great influence: the country shares much more with the United States in the field of law, traditions and principles, rather than with EU countries, so much so that they are many support the need to direct the development of the British economy towards the American one. The United Kingdom, like the United States, is in fact focused on the development of private property, traditional market relations, freedom, business and competition.

The presence of the same currency for most EU Member States is a vulnerable point of the European Union: the common currency is extremely disadvantageous for economically less developed countries, which are forced to continually increase the own debt to cope with the inefficiency of balance of payments regulation mechanisms. A country that holds a national currency can indeed devalue it to increase the competitiveness of its exports by reducing the volume of imported goods. It therefore happens that within the euro zone, while economically strong countries like Germany close the balance sheets positively, others, with a less competitive economy like Greece, are forced to increase debt through austerity instruments, bringing to the escape abroad of specialized personnel and making then the country even less competitive.

Investments, and capital in general, are notoriously moving where the markets are more

\footnotetext{
${ }^{7}$ Data source: House of Commons Library, The 1974-75 UK Renegotiation of EEC Membership and Referendum. Published Monday, July 13, 2015

${ }^{8}$ Data Source: legislation.gov.uk - Changes to Legislation (https://www.gov.uk/government/organisations /department-for-exiting-the-european-union).
} 
capacious, the incomes are the highest, the workers are the most qualified and highly paid and where more added value is created, namely in Germany itself, in France and in many other small but highly developed European countries; this factor also crumbling the EU by increasing inequalities between member states. It turns out then that a periphery is being created within the Union, represented mainly by Greece and other southern European countries, by post-Soviet and post-socialist states (Bulgaria, Romania, Hungary, the Baltic States, etc.); an area that, although must somehow be supported by the EU, does not receive the necessary support due to the political and economic model of the Union which tends to reflect the interests of the most developed Member States, primarily Germany.

Below it is possible to note, besides the situation of the United Kingdom, also the remarkable difference, in terms of growth, between the two member countries economically placed at the antipodes: Germany and Greece.

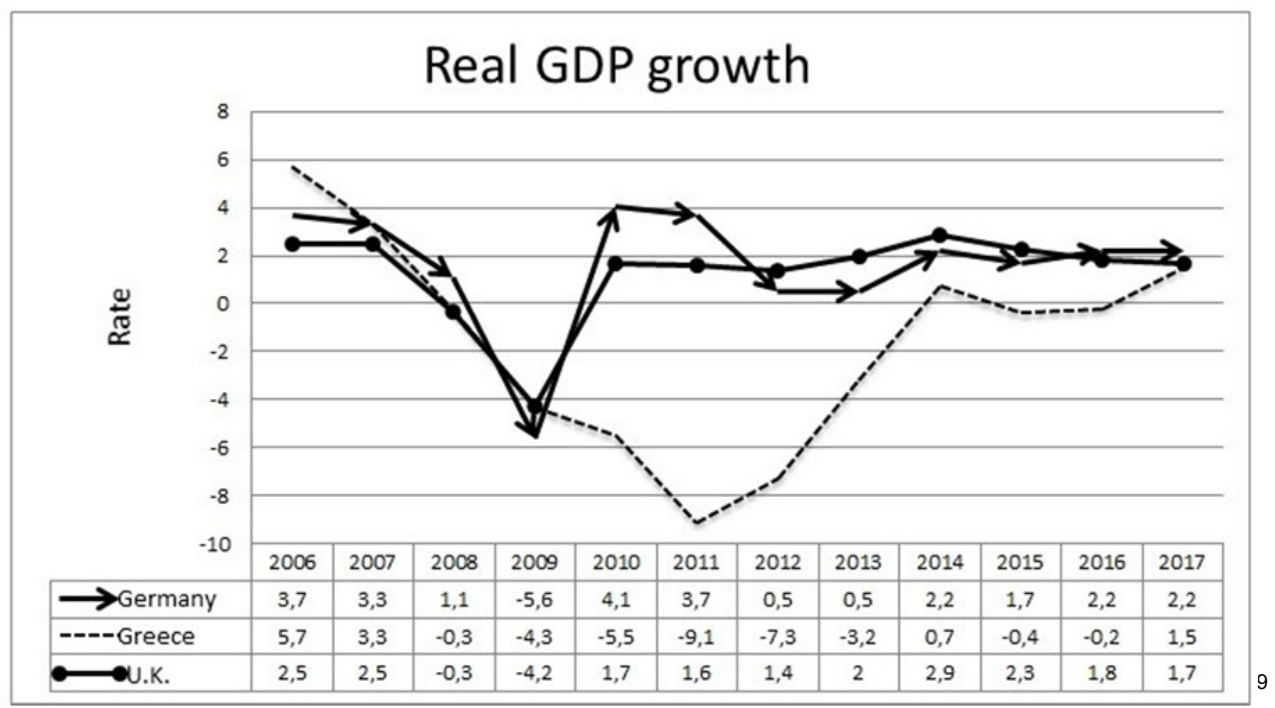

As regards social and security policies, an integral part of the European integration process is the development of a common immigration policy; the problem is that traditionally this is the responsibility of national governments. The general immigration regime provides for the coordination of the objectives, priorities and scope of the migration policies of the participating countries. The immigration problem has been brought to the fore in the United Kingdom. The main reasons are competition problems for jobs, government services, social housing, education or health care. Issues should be addressed at national level. This therefore leads to a contradiction between international obligations and state competences. In 2012, David Cameron, speaking at the annual conference of the Confederation of British Industry $(\mathrm{CBI})$, declared the need to control immigration also through the introduction of "quotas" or "restrictions" for access to the country even for those that they came from other Member States. From the Union point of view, such a policy is unacceptable; the United Kingdom is indeed obliged to adhere to a pan-European immigration policy. In this regard, a clash broke out between Great Britain and Germany: in particular, the German chancellor A. Merkel repeatedly declared that he did not intend to compromise on the question of free movement, considering it one of the fundamental principles of European integration.

${ }^{9}$ Data source: Eurostat, Real GDP growth rate - volume [TEC00115].Last update: 09/07/2019. Graphic elaborated by Alessandro Rossetti. 


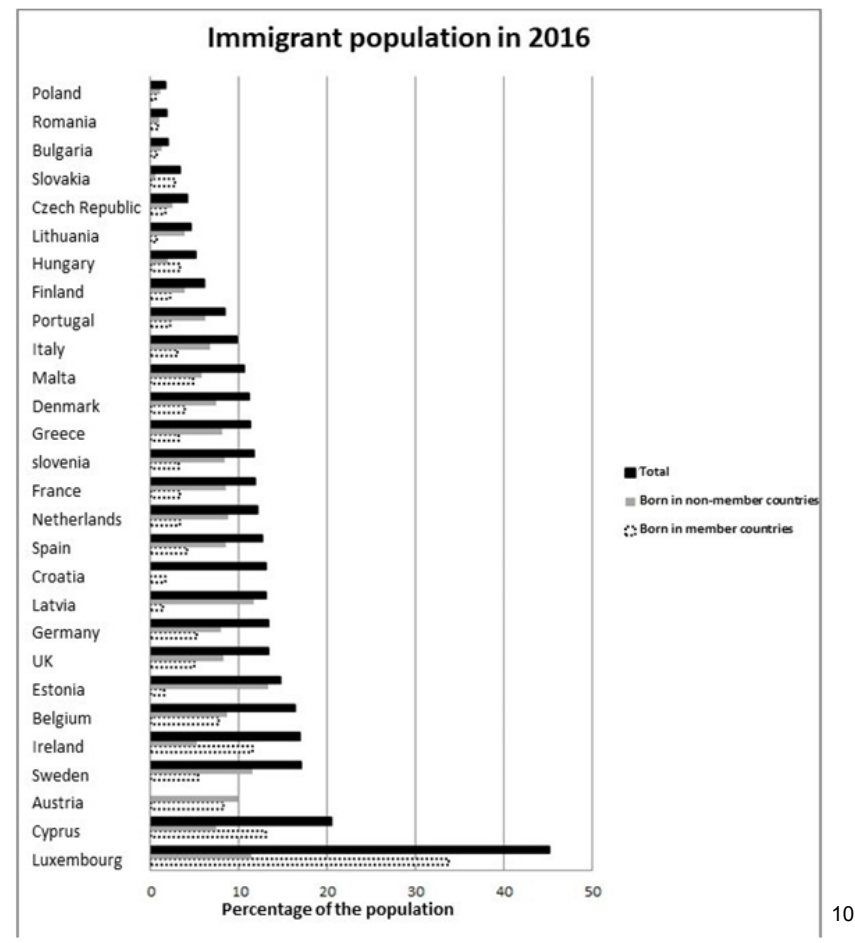

The increase of immigration in Great Britain, quintupled between 1997 and $2004^{11}$, and continued to increase enormously in the years immediately preceding Brexit, produced a strong reaction among voters who were very worried about it. At the time of the referendum, the immigration issue was already at the top of the political agenda for over a decade. The majority of voters advocating a reduction in immigration, realizing how much the EU represented a key obstacle to achieving this goal, have consequently become more skeptical about maintaining EU membership. The anxieties about the negative effects perceived regarding the migration phenomenon, were further fomented by a populist press. Although both Labor and Conservatives were acutely aware of this growing concern, neither could find an effective answer, due to the "constraints" imposed by Brussels: in an area of free movement, in which EU citizens were free to work and settle down, strict immigration controls were simply impossible despite the numerous electoral promises. This obviously meant that the campaign in favor of leave was particularly focused on immigration, stating that more than half of the net migration came from the member countries

The country's choice to leave the EU is also explained by the fact that the union is no longer solid and successful; in the past it was perceived as a very promising integrative model. However, at this stage, the EU is experiencing a systemic crisis, starting from the financial one that has lasted for many years, to the spiritual one with the destruction of moral values and the growth of radical feelings in society. At the center of the collapse of the Greater Europe project, there is precisely the uncertainty of the policies pursued by the West over the years.

Despite the fact that the EU has achieved rather broad economic and technological successes against the background of this progress, this crisis process is emerging. This tendency, together

\footnotetext{
${ }^{10}$ Data source: Eurostat - Immigration persons. Code: TPS00176. Last update: 16/04/2019. Graphic elaborated by Alessandro Rossetti

${ }^{11}$ Data source: Office for National Statistics. Explore 50 years of international migration to and from the UK. $1^{\text {st }}$ December 2016.
} 
with all the spheres of public consciousness, also manifests itself in the political sphere with the increase in unemployment, radicalism and intolerance towards other cultures.

The United Kingdom, which has not entered the European monetary system and the Schengen area, is today the most powerful international financial center, foreshadowing a future in which the country could take the lead of an autonomous Atlantic community; Britain is in fact closely linked to states that belong to the Commonwealth, as well as having strong links with former colonies, such as India.

The main reasons for posting between the UK and the EU are:

- Britain's reluctance to subsidize weaker economies

- EU social policy towards migrants and freedom of movement of workers;

- The principle of supranational control over the economy, finances, laws;

- EU agricultural policy;

- Labor law focused on social benefits;

- The growing instability in the world causes dissatisfaction and discontent in the population;

- The EU systemic crisis: financial crisis, economic decline, spiritual crisis, destruction of moral values.

The European Union has never been homogeneous economically, politically and culturally and in recent years this heterogeneity has been accentuated, above all for the reasons we have seen. The most acute migratory emergency following the debt crisis in the euro area, has already led to a sharp decline in intra-EU solidarity; The migrants once again put the compactness of the union to the test: illegal entries in violation of national regulations, the Schengen rules and the Dublin criteria, have led to continuous debates between the various European leaders, mostly interested in "updating" or not the old agreements. Precisely the continuation of this undecided policy of the European authorities has seriously compromised the effectiveness of the legal system, as well as the very idea of European integration, a model far from perfect.

The EU would need a serious institutional modernization to get out of the crisis: the decisionmaking system behind it is too cumbersome and complex, extremely bureaucratic and ineffective in terms of management. The United Kingdom vote transforms the configuration of forces in Europe and calls into question the whole European future. The referendum had great resonance in society, giving rise to two diametrically opposed factions; specifically, the country's exit will have consequences both internally, in Great Britain, and in Europe: in terms of foreign policy, the United Kingdom will lose its influence over Brussels, Paris and Berlin, a fundamental instrument that guaranteed it achieve their foreign policy objectives more easily.

On the other hand, the EU without the United Kingdom will weaken in favor of France, which will have the burden of representing Europe in the UN Security Council. For Great Britain itself, Brexit makes no difference in this regard, since it will remain a key member of NATO and of the United Nations Security Council.

With Brexit, the EU could see its weight lightened on the world stage: without Great Britain, the Union will have less chance of using sanctions as a means of pressure, given the strong support of the United Kingdom for the use of instruments of this type, as in the case of the Crimea when Prime Minister David Cameron, dragging the other member states with him, established that Russia should pay for its own actions. Furthermore, due to the exit of the United Kingdom, EU positions in Asia, already weakened by the Eurozone crisis, will weaken further. It could happen that the ASEAN countries no longer perceive the EU as a model of regional political integration. In addition, the loss of the second EU economy will lead to a decrease in European negotiating positions in free trade negotiations with countries like Japan and India.

Consequently, the detachment of Great Britain will increase the dominant influence of Germany that could move towards a political union, given the probable risk of a knock-on effect: in the Old Continent, the Eurosceptic sentiment is actually intensifying against the background of the migration crisis already discussed above.

As for the internal problems of the nation, the danger for the United Kingdom, in the event of its exit from the EU, will be the likelihood that Scotland will hold another referendum on secession from Great Britain. Without Scotland, British power will weaken enormously: together with a part of 
the population, the United Kingdom will be deprived of important oil reserves and potentially also the possibility of using different naval bases in the country.

On an extra-national level, it is feared that Brexit will reawaken nationalistic and independence passions in Europe, as in the case of Catalonia.

Supporters of Brexit believe that:

- withdrawal from the European Union will strengthen democracy, since the parliament will become fully sovereign, no longer subject to European laws and regulations, although British citizens will most likely lose the advantage of free movement and residence in Europe.

- excessive immigration causes significant social problems

- in the absence of European bureaucracy and its innumerable rules, small and mediumsized enterprises will prosper, which will lead to an increase in employment.

Supporters of the remain affirm instead that:

- Despite some difficulties in providing public services, in general, immigration has had a positive effect on the British economy.

- With Brexit, millions of jobs will be lost, as multinational companies will transfer production to other EU countries; this will affect the automotive industry in particular, almost entirely owned by foreign companies.

- With Brexit, there will be serious repercussions on the financial sector, which employs about 1.3 million British ${ }^{12}$ and bases its success on its European market.

From a political point of view, one of the first results of the referendum was the resignation of British European Commissioner, Baron Hill, on June 25, 2016. On the evening of Tuesday, June 28, at the summit of the European Council in Brussels, the symbolic descent of the British flag took place in front of the European Commission building. Discouraged by the outcome of the referendum, David Cameron therefore decided to leave the prime minister's seat. On July 13th, the Secretary of State for Internal Affairs, Theresa May, begins the formation of a new government, immediately creating two special ministries, the one for leaving the EU and the one for international trade.

From an economic point of view, on the other hand, the EU is the UK's main trading partner covering $52 \%$ of British exports of goods and services ${ }^{13}$. However, the full exit from the European Union will lead to the emergence of trade barriers; this means, for example, that a $15 \%$ tariff will be imposed on cars produced in Great Britain and $10 \%$ on cars imported from Europe.

The United Kingdom will therefore have to revise the trade agreements with the EU states. However, the supporters of leave say that the European Union, as a market, is not as important for Britain as it was in the past, and that the current crisis in the euro area will only reinforce this trend.

With the help of the WTO, the United Kingdom will be able to conclude bilateral trade agreements with countries characterized by rapidly growing economies, such as with China, Singapore, Brazil and India, as well as with Russia. Much will depend on the type of treaties that the British will be able to sign. For Great Britain, there are several options for maintaining trade relations with EU countries:

- The Norwegian option: the United Kingdom leaves the EU and joins the European Economic Area, with the possibility of accessing the Community market, exception for part of the financial sector.

- The Swiss option: the United Kingdom will follow the example of Switzerland, which is not part of the EU or the EEA, but concludes separate agreements with Brussels for each economic sector.

- Turkish option: the United Kingdom can enter a customs union with the EU, with free access to the European market, except for the financial sector.

- The United Kingdom could also try to conclude a global free trade agreement with the EU on the Swiss model, but with guarantees of access to the European financial market, as well as a certain degree of control over the formulation and implementation of the general rules of trade.

\footnotetext{
${ }^{12}$ Data source: Office for National Statistics. EMP13: Employment by industry. 14 May 2019.

${ }^{13}$ Data source: House of Commons Library. Statistics on UK-EU trade. Number 7851, 11 January 2019.
} 
- The United Kingdom can completely interrupt its relations with the EU and rely solely on WTO rules.

According to "Open Europe Today report", in aworst case scenario, "UK GDP could be 2.2\% lower in 2030 if Britain leaves the EU and fails to strike a deal with the EU or reverts into protectionism". However, still according to the same source, "In a best case scenario, under which the UK manages to enter into liberal trade arrangements with the EU and the rest of the world, whilst pursuing large-scale deregulation at home, Britain could be better off by $1.6 \%$ of GDP in 2030 "14.

Therefore, while on the one hand, in the long run, London could lose its importance as a global financial center, on the other, by becoming completely independent of EU requirements, it could become one of the major economic powers, such as Singapore.

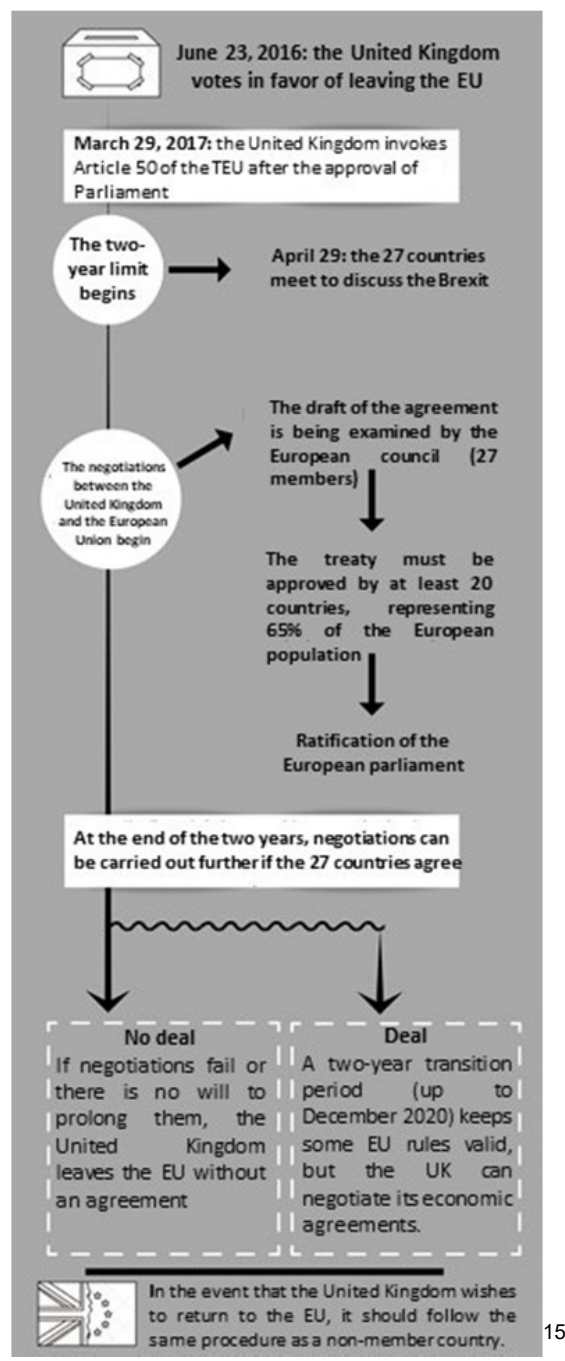

${ }^{14}$ Source: Open Europe Today. "What if...? The consequences, challenges and opportunities facing Britain outside the EU", (https://openeurope.org.uk/intelligence/britain-and-the-eu/what-if-there-were-a-brexit/), 2015.

${ }^{15}$ Main steps towards the exit of the United Kingdom. Graphic elaborated by Alessandro Rossetti. 
Regarding European macroeconomic policy, Brexit could play an important role in the energy field, further strengthening German influence in this sector: the United Kingdom has always opposed the European Commission's efforts to intervene in national energy policies aimed at ensuring the security of the Union. Therefore, without the UK, the EU could adopt a more centralized system for regulating the common energy market. Still in the energy field, Brexit could cause a further limitation to the use of coal in combination with a more centralized system of redirection of energy flows, including gas, to the countries that need it. In this sense, Germany's desire to strengthen its control over the EU energy sphere is clearly visible, aiming to become a strategic crossroads for the supply of gas, increasing imports from Russia also through the "Nord Stream" pipeline.

\section{Brexit and defense policy}

As far as defense policy is concerned, the proponents of exit from the EU tend to overlap the concept of open borders with that of open doors to illegal immigration; for this reason, the closure of the borders will allow a more effective control of the flow of immigrants arriving in the United Kingdom.

On the other hand, opponents of the exit, including some senior military officials, believe that the European Union is an essential element of security, as it allows, through its agencies like Europol and Eurojust, to share easily sensitive information related to crime. It is therefore likely that with the Brexit , the United Kingdom's foreign security policy is leaning towards NATO.

Without the United Kingdom, the 27 remaining Member States could more easily promote the common defense policy. On the background of these political crises, the EU has understood, in fact, how necessary it is to be guided by its own national interests, and not by the US ones; in this regard, a further expansion of NATO would inevitably lead to the emergence of new and deeper divisions existing in Europe, increasing the fragmentation of the European security space, further complicating relations between Russia and the EU. At the same time, it is obvious that NATO forces can neither stop the flow of refugees nor contribute, for example, to solving the Ukrainian conflict; the countries of the European Union, in front of the inefficiency of the Atlantic alliance, favor the creation of a single European army, a sort of unique political-military bloc structurally different from NATO. Precisely in this regard, Great Britain not only had previously made criticisms, but it had also promised to veto any proposal concerning the creation of a "European army". This was stated by British Defense Minister, Michael Fallon, arguing that there was no possibility of creating this body.

The heads of the military departments of Germany and France have therefore developed new proposals to improve activities in the field of European Union defense policy, such as the creation of a joint command headquarters, a common satellite system and an exchange system of logistic and military medical resources.

Having your own army would allow Western countries to conduct their own operations, without necessary NATO support, in which, among other things, not all members of the European Union are present: Sweden, Finland, Austria, Ireland, Cyprus and Malta are excluded. However, according to the NATO-EU partnership agreement for peace, these countries can also count on the military support of the alliance, despite trying to maintain a state of neutrality. From an economic point of view, finally, the creation of a unified army would significantly reduce military spending. Savings of around $€ 120$ million have been estimated.

However, with Brexit, the EU will lose one of its most important military powers in Europe and one of the few countries that employ $2 \%$ of its GDP in defense ${ }^{16}$. In this sense, while Brexit could encourage EU Member States to increase funding for a common European defense project, on the other hand the desire to create defense structures outside NATO will have to come to terms with a not inconsiderable initial cost and not easy to finalize, both from a purely economic and political point of view, given the spread of Eurosceptic and nationalist movements.

${ }^{16}$ Data Source: House of Commons Library. UK Defence Expenditure. Number CBP 8175, 8 November 2018. 
NATO Secretary General, Jens Stoltenberg, said that the Alliance needs both a strong UK and a strong Europe; the alliance is facing "unprecedented challenges to security, terrorism, instability and unpredictability. A fragmented Europe will only aggravate these problems". NATO is particularly concerned that, after the Brexit, the simplified communication system between Washington and the EU, within the Union and NATO, will be interrupted. The withdrawal of Great Britain would therefore risk collapsing all the western security system built in the past decades.

\section{Conclusion}

In conclusion, we have seen how the process of disintegration of the EU started by leveraging on various factors, from the economic to the social and political to the identity. For Great Britain, it is conceptually unacceptable that the EU develops behind the federal principle; In fact, this would deprive it of its traditional belief in national identity and sovereignty. Since there have never been similar cases to Brexit, the United Kingdom will inevitably have to face a series of problems, starting with the uncertainty on how to develop future relations with the European Union, by passing for the need to modernize the vulnerable British political-constitutional system: the current government institutions and the governance mechanisms that have formed over the centuries are, in fact, clearly obsolete.

From the EU point of view, Brexit obviously represents a shock, a heavy blow to its reputation, as long considered an exemplary form of integration process. For the European Union, therefore, it is necessary to intensify actively the processes of modernization, from the development of some common strategic objectives, to the reform of existing institutions and bodies.

Whatever approach the government pursues in applying the referendum verdict, it is a fact that the Brexit has accelerated the polarization of values, perspectives and priorities that separate more and more the cosmopolitan university educated by the low-skilled nationalists.

The 2016 referendum has laid bare the deep divisions between these groups, placing them on diametrically opposed sides and forcing the main parties to confront the internal conflicts that persist between the leavers and the remainers, among those who wish to give priority to access to the single market, and those who wish to prioritize the strong obstacles to free movement and migration. All this conditions were a big challenge for the former Prime Minister Teresa May and as we saw the cause of his demission and we can confirm the idea of MJ Goodwig "This puts Prime Minister Theresa May in the difficult position of trying to negotiate a new agreement with the EU that maximizes access to European markets for the City of London, while including the more radical immigration reform that Leave voters clearly want"17. In any case today we are in front of uncertain situation, the future of Brexit is increasingly shrouded in fog with Prime Minister Boris Johnson who, contrary to what was approved by parliament, would be pushing for Britain to come out of the European Union, anyway on October 31st.

A transitional agreement could alleviate these pressures, but it would be unlikely (at least initially) to implement immigration restrictions; on the other hand, if the government had to give priority to this aspect, the economy could suffer consequences as strong as unpredictable, thus opening a new window of opportunity for the populists of the radical right. In the United Kingdom, negotiating an exit agreement with the EU is today the main political challenge for the government. The exit of the United Kingdom will imply a new economic orientation which, for the country, will result in the loss of community privileges with all that this entails: from the payment of duties, to the need to sign new trade agreements. The consequences of the exit will obviously depend on the diplomatic skills of the United Kingdom and the related decisions that will be made by the EU. However, the real future challenge for the country will be to respond to the divisions laid down by Brexit. Brexit is postponed until at least October 31st, prolonging uncertainty especially in the United Kingdom; at the risk of deteriorating confidence with a depreciated pound $(-9.5 \%$ compared to pre-Brexit levels). Politics does not want to solve the problem, but the economy cannot wait long.

${ }_{17}$ Matthew J. Goodwin in Brexit: Causes \& Consequences, https://www.jef.or.jp/journal/pdf/216th_Recent _JEF_Activity_02.pdf 


\section{References}

Eurostat - Immigration persons. Code: TPS00176. Last update: 16/04/2019;

Evans G. and Menon A. (2017) Brexit and British Politics. Cambridge: Polity Press.

Baldini G. (edited by), (2019) La Gran Bretagna dopo la Brexit, II Mulino, Bologna.

Figus A., (2019), Sistema Europa. Uno sguardo oltre, Eurilink, Roma.

Figus A., (2010), Sistema Europa. L'organizzazione politica dell'Unione Europea, Eurilink, Roma.

House of Commons Library, Education: Historical statistics. Last updated: 27 November 2012. Author: Paul Bolton;

House of Commons Library. UK Defence Expenditure. Number CBP 8175, 8 November 2018;

House of Commons Library. Statistics on UK-EU trade. Number 7851, 11 January 2019;

Koller V., Kopf S. and Miglbauer M. (edited by), Discourses of Brexit, Routledge, 2019;

Office for National Statistics. Explore 50 years of international migration to and from the UK. 1st December 2016.

Office of National Statistics, 2011, Census;

Office for National Statistics. EMP13: Employment by industry. 14 May 2019;

Oliver T., Understanding Brexit: A concise introduction. Bristol: Policy Press, 2018.

\section{Web}

https://www.barcouncil.org.uk/media/508513/the_brexit_papers.pdf

https://www.electoralcommission.org.uk/

http://www.europarl.europa.eu/unitedkingdom/en/brexitpublic/brexitstudies.html

https://www.gov.uk/government/brexit

https://www.ilfoglio.it/la-versione-di-cassese/2019/03/26/news/cosa-insegna-la-brexit-245321/

https://www.gov.uk/government/organisations/department-for-exiting-the-european-union

http:// https://openeurope.org.uk/intelligence/britain-and-the-eu/what-if-there-were-a-brexit/

https://publications.parliamhttps://www.parliament.uk/business/news/european-union/

ent.uk/pa/ld201719//dselect//deucom/245/245.pdf 